Journal of Telenursing (JOTING)

Volume 2, Nomor 1, Juni 2020

e-ISSN: 2684-8988

p-ISSN: 2684-8996

DOI: https://doi.org/10.31539/joting.v2i1.1095

\title{
PEMBERIAN MINYAK TELON DALAM UPAYA MENCEGAH PERUT KEMBUNG PADA BAYI BARU LAHIR
}

\author{
Gina Permatasari ${ }^{1}$, Nining Hening Pramesti ${ }^{2}$, Sri Mulyani Nurhayati ${ }^{3}$ \\ Akademi Keperawatan Pelni Jakarta ${ }^{1,2,3}$ \\ ginapermatasari90@gmail.com ${ }^{1}$
}

\begin{abstract}
ABSTRAK
Tujuan penelitian ini untuk mengetahui dengan dilakukannya pemberian minyak telon pada bayi baru lahir dapat mencegah perut kembung. Jenis penelitian ini deskrptif sederhana dengan pendekatan studi kasus. Hasil penelitian kepada kedua subjek penelitian yaitu pada By. Ny. A pada hari pertama sebelum diberikan pemberian minyak telon lingkar perut $29 \mathrm{~cm}$, dengan keadaan perut lembek, tidak banyak bergerak, tidak sering menangis tanpa sebab dan setelah dilakukan penelitian Subyek Penelitian I tidak terjadi kembung, tetapi pada saat hari ketiga perut agak sedikit keras. Simpulan, saat melakukan pengkajian bayi memiliki masa gestasi sesuai dengan kriteria inklusi dan melakukan intervensi pemberian minyak telon dengan mengunakan minyak telon pada perut bayi.
\end{abstract}

Kata Kunci: Bayi Baru lahir, Minyak Telon, Perut Kembung

\section{ABSTRACT}

The purpose of this study was to determine the administration of telon oil to newborns to prevent flatulence. This type of research is simple descriptive with a case study approach. The results of the investigation to the two research subjects, namely By. Mrs. A on the first day before giving telon oil $29 \mathrm{~cm}$ circumference of the abdomen, with a soft stomach, not moving much, not crying often without cause, and after conducting research Research Subject I did not occur bloating. Still, on the third day, the stomach is a bit hard. In conclusion, when carrying out the assessment of the baby has a gestation period following the inclusion criteria and intervene in giving telon oil using telon oil on the baby's stomach.

Keywords: Newborns, Telon Oil, Flatulence

\section{PENDAHULUAN}

Masalah pencernaan pada bayi baru lahir pada umumnya dikarenakan saluran pencernannya masih belum matang (Padila et al., 2018). Bayi yang tadinya menerima nutrisi melalui plasenta ibunya saat dalam kandungan, ketika lahir baru mulai beradaptasi dengan saluran pencernaannya sendiri untuk mencerna dan menyerap nutrisi (Padila, 2015). Beberapa enzim pencernaan belum langsung tersedia dalam jumlah yang cukup saat lahir, dan baru akan mencapai kadar yang cukup seiring dengan bertambahnya usia. Aktivitas dan fungsi beberapa organ pada anak di usia awal kelahirannya belum optimal sehingga para orangtua yang telah paham akan menyesuaikan dan menstimulasi sedikit demi sedikit (Padila et al., 2019). 
Enzim'enterokinase' dalam sistem pencernaan anak yang fungsinya mengaktivasi enzim untuk memecah protein, baru aktif sebanyak 25\%, sedangkan 'laktase' yang berfungsi memecah laktosa yang terdapat dalam susu, juga baru aktif sebanyak $70 \%$ kapasitasnya saat bayi masih di usia dini. Pada saluran cerna yang telah matang, saat makanan dicerna, makanan akan dipecah secara kimiawi menjadi bentuk yang lebih kecil sehingga dapat diserap oleh tubuh. Karena pada sebagian bayi enzim pencernaan belum tersedia dalam jumlah yang cukup, maka sebagian makanan yang masuk tidak dapat dipecah secara kimia dan tidak tercerna sempurna (Martha, 2016).

Kembung (meteorism, tympanities) ialah suatu simtom/gejala yang menunjukkan adanya udara atau gas dalam rongga abdomen atau usus. Distensi abdomen adalah kesan secara inspeksi adanya abdomen lebih besar dari ukuran biasa pada anak. Distensi abdomen mungkin disebabkan oleh adanya masa abdomen atau oleh karena penumpukan cairan atau gas Distensi abdomen pada bayi dan anak biasanya merupakan manifestasi suatu penyakit (Padila et al., 2019). Distensi dapat timbul secara akut maupun kronik. Kembung meteoristimus ) adalah pembesaran abdomen terjadi karena usus terisi udara, abdomen akan timpanik (kembung), tidak teraba masa dan tidak ada gelombang cairan. Adanya akumulasi gas/udara yang berlebihan sering menjadi keluhan pasien prevalensi keluhan yang berhubungan dengan akumulasi gas dalam usus pada anak tidak diketahui, sedang pada populasi dewasa secara umum dilaporkan sebanyak 10\%-30\%. Beberapa gejala yang berhubungan adanya akumulasi gas dan bebeberapa penyakit dengan gejala yang berhubungan adanya gas dalam usus seperti eructation, kentut, bloating, distensi abdomen dan nyeri abdomen perlu dieksplorasi. Penggunaaan uji pernafasan dapat dilakukan untuk menilai penyebab gejala tersebut. Kolik pada bayi (kolik infantil) sering sebagai akibat akumulasi gas 2342 dalam usus (IDAI, 2017).

Akumulasi gas yang berlebihan dalam lumen usus akan menimbulkan berbagai gejala: eructation, kembung, borborygmi, flatus, nyeri perut. Gejala-gejala ini dapat berupa keluhan tunggal atau berhubungan dengan keluhan tambahan yang berasal dari dalam atau luar usus. Nyeri perut hilang atau berkurang setelah flatus (IDAI, 2017). Sering penderita (bayi, anak dan dewasa) atau orang tuanya mengeluh seperti diatas dengan jumlah gas usus yang normal. Kebanyakan orang tua berharap anaknya yang mengalami kembung/ peningkatan gas dalam usus dapat flatus (Padila et al., 2018). Selain itu mengeluh bila terjadi refleks gastrokolik (misalnya timbul gas setiap kali makan). Adanya gas yang berlebih dalam usus dapat menyebabkan anak rewel. Anak yang sering menangis akan menghirup udara yang berlebih sehingga menyebabkan peningkatan gas dalam usus dan flatus serta beresiko muncul gejala pada sistem pernafasan (Padila et al., 2019).

Perawat maternitas sebagai salah satu tenaga kesehatan memiliki peranan yang sangat penting untuk ikut serta mengatasi gangguan pencernaan melalui berbagai peranan yaitu peran perawat sebagai care giver seperti mencegah perut kembung dapat dilakukan perawat maternitas yaitu dengan memberikan minyak telon untuk mencegah perut kembung sehingga bayi dan ibu menjadi nyaman. Diperlukan juga peran perawat sebagai edukator seperti diharapkan dapat membantu mengatasi mencegah terjadinya kembung dalam upaya pencegahan perut kembung pada bayi baru lahir dalam melakukan perawatan perut kembung (Padila, 2015).

Daging buah kelapa segar sebagai bahan baku VCO memiliki kandungan minyak $34,7 \%$, protein $3,8 \%$, air $46,9 \%$ dan karbohidrat $14,6 \%$, sedangkan komponen VCO sendiri berupa asam lemak jenuh sekitar $90 \%$ dan asam lemak tak jenuh sekitar $10 \%$. 
Asam lemak jenuh VCO didominasi oleh asam laurat. VCO mengandung $\pm 51,24 \%$ asam laurat dan sekitar 7,91\% asam kaprilat. Keduanya merupakan asam lemak rantai sedang yang biasa disebut Medium Chain Fatty Acid (MCFA). Komposisi masingmasing minyak dalam minyak telon (minyak kelapa : minyak adas : minyak kayu putih : minyak kelapa) adalah 3:3:4 (Solarbesain \& Pudjihastuti, 2019).

Minyak telon juga kerap dimanfaatkan ibu untuk mencegah terjadinya perut kembung pada bayi. Sistem pencernaan bayi baru lahir belumlah berfungsi dengan sempurna, sehingga amat mudah mengalami kembung. Perut bayi yang kembung ditandai dengan bunyi yang khas ketika ditepuk-tepuk. Rasa tidak nyaman pada perut bisa menimbulkan kolik yang menyebabkan bayi menangis melengking tiba-tiba di jamjam tertentu. Untuk mengurangi kemungkinan kembung dan perut tidak nyaman, minyak telon dapat digunakan. Minyak telon bermanfaat untuk mencegah dan mengobati perut kembung pada bayi dan memberikan rasa hangat pada bayi. Selain itu minyak telon dapat meringankan gejala kolik/mulas pada bayi. Sistem pengaturan panas tubuh bayi belum sempurna, terutama pada awal kehidupannya. Akibatnya, ketika suhu sekitarnya dingin, bayi pun mudah merasakan kedinginan dan bisa menggigil (Martha, 2016).

\section{METODE PENELITIAN}

Jenis penelitian ini adalah deskriptif, peneliti akan melibatkan 2 pasien yang akan diberikan intervensi pemberian minyak telon pada bayi baru lahir dalam mencegah kembung. Dengan menggunakan metode studi kasus ini penulis dapat memperoleh informasi yang mendalam tentang pemberian minyak telon pada bayi baru lahir untuk mencegah perut kembung.

Penelitian ini melibatkan 2 individu yaitu dua bayi baru lahir yang dipilih secara purposive random sampling. Pemberian minyak telon dalam upaya mencegah kembung pada bayi baru lahir dengan karakteristik yang sama yaitu kedua klien sama-sama melakukan terapi. Pada subyek I dilakukan pemberian minyak telon selama 5 hari dalam waktu 15 menit dilakukan pada sore hari, pada Subyek II dilakukan pemberian minyak telon selama 5 hari dalam waktu 15 menit pada waktu pagi hari.

Penelitian ini dilakukan mulai tanggal 15 Juli 2019 sampai dengan 24 Juli 2019 diruang Kenari Rumah Sakit Pelni Jakarta dilanjutkan ke rumah pasien. Subjek penelitian I pada tanggal 15-19 Juli 2019, subjek penelitian II 18-22 Juli 2019. Penelitian studi kasus ini dilakukan di Ruang Kenari Bayi Rumah Sakit Pelni Jakarta yang beralamat di Jl. KS Tubun No. 92-94 Jakarta Barat. Di ruang Kenari bayi terdapat ruang blue light, ruang menyusui, ruang khusus bayi baru lahir infeksius, ruang bayi baru lahir sehat, ruang untuk memandikan, ruang untuk edukasi dan menyusui, dan nurse station. Kondisi di ruang Kenari bayi rapih, bersih, nyaman, dilengkapi dengan alat-alat yang memadai, di Ruangan ini sudah dilakukan perawatan rooming in intermiten atau perawatan ibu dan bayi bersama-sama pada tempat yang berdekatan sehingga memungkinkan setiap saat ibu dapat menyusui bayinya.

Penelitian yang penulis lakukan di ruang bayi sehat pada hari pertama, selanjutnya penulis mengadakan penelitian yang di lanjutkan ke rumah subyek I dan subyek II. Kondisi subjek I sebelum dilakukan intervensi adalah perut bayi tidak keras, perut bayi tidak tampak besar, lingkar perut bayi $30 \mathrm{~cm}$, bayi tidak rewel, warna kulit merah muda, bayi bergerak aktif, BAB dan BAK sebanyak 2 kali, dan kondisi subyek penelitian I dalam keadaan baik. Kondisi subjek II sebelum dilakukan intervensi adalah perut bayi 
tidak keras, perut bayi tidak tampak besar, lingkar perut bayi $31 \mathrm{~cm}$, bayi tidak rewel, warna kulit merah muda, bayi bergerak aktif, BAB dan BAK sebanyak 3 kali, dan kondisi subyek penelitian I dalam keadaan baik.

Kondisi subjek penelitian saat proses intervensi selama 5 hari dengan diberikan minyak telon pagi dan sore setelah mandi pada subjek penelitian I dan subjek penelitian II.

\section{HASIL PENELITIAN}

Tabel. 1

Proses Intervensi Subjek Penelitian I

\begin{tabular}{|c|c|c|c|}
\hline Pertemuan & Tindakan dan Tujuan & Respon & Kemajuan \\
\hline $\begin{array}{l}\text { Pertemuan } \\
\text { Pertama }\end{array}$ & $\begin{array}{l}\text { 1. } \begin{array}{l}\text { Tercipta hubungan } \\
\text { saling percaya }\end{array} \\
\text { 2. Mendapat persetujuan } \\
\text { penelitian dari subyek } \\
\text { 3. Mengetahui tingkat } \\
\text { pengetahuan orang tua } \\
\text { Subyek I tentang } \\
\text { pemberian minyak } \\
\text { telon } \\
\text { 4. Mampu mengikuti } \\
\text { pemberian minyak } \\
\text { telon setelah mandi } \\
\text { 5. Mencegah kembung }\end{array}$ & 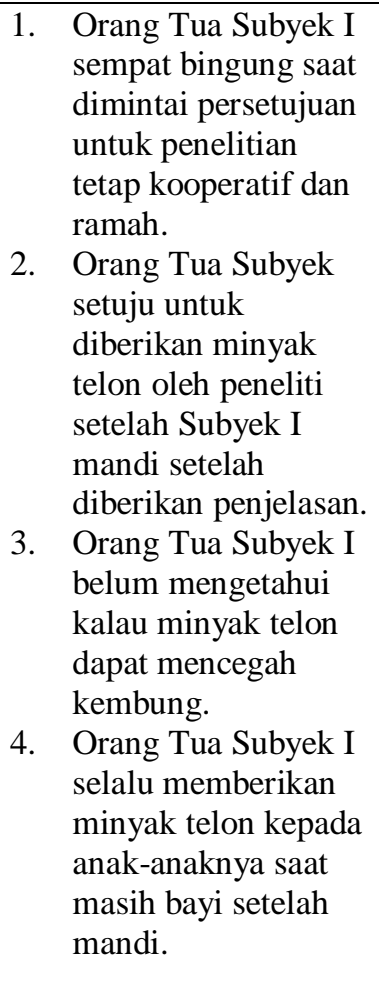 & 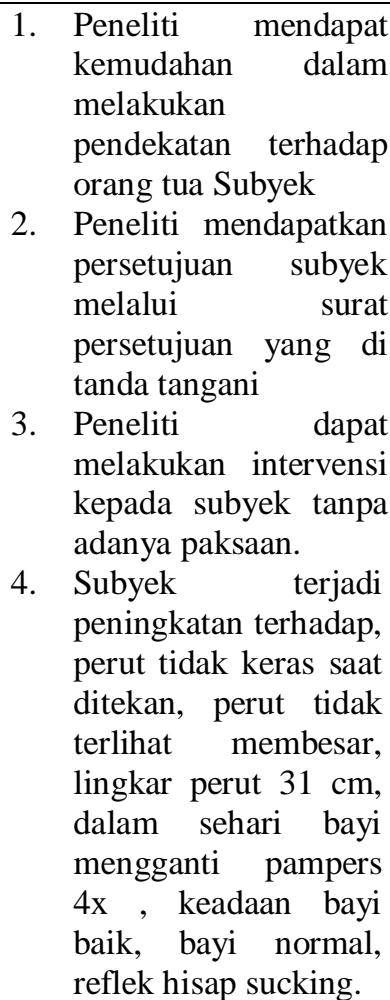 \\
\hline $\begin{array}{l}\text { Pertemuan } \\
\text { Kedua }\end{array}$ & 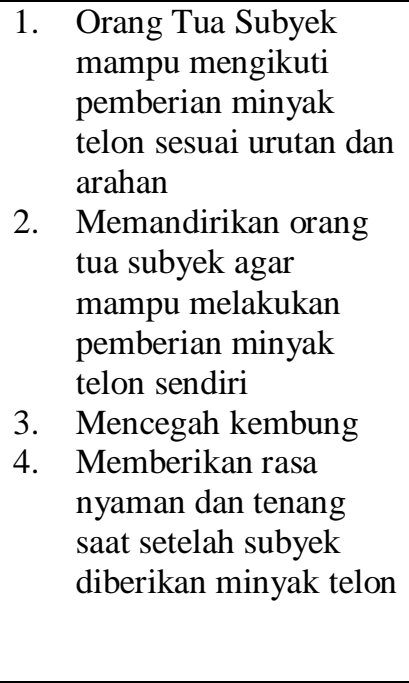 & 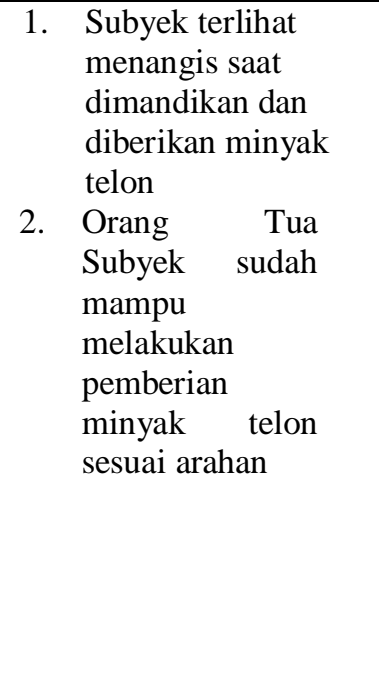 & 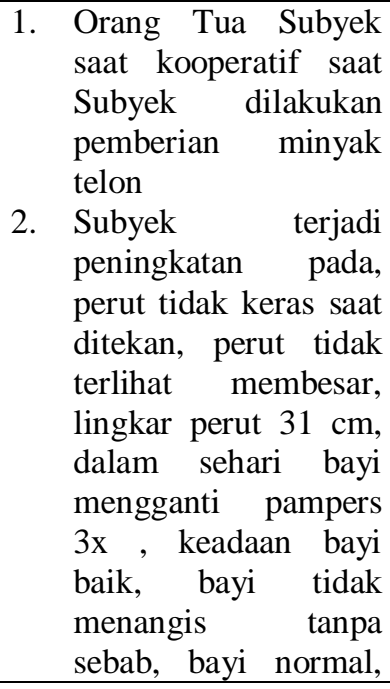 \\
\hline
\end{tabular}




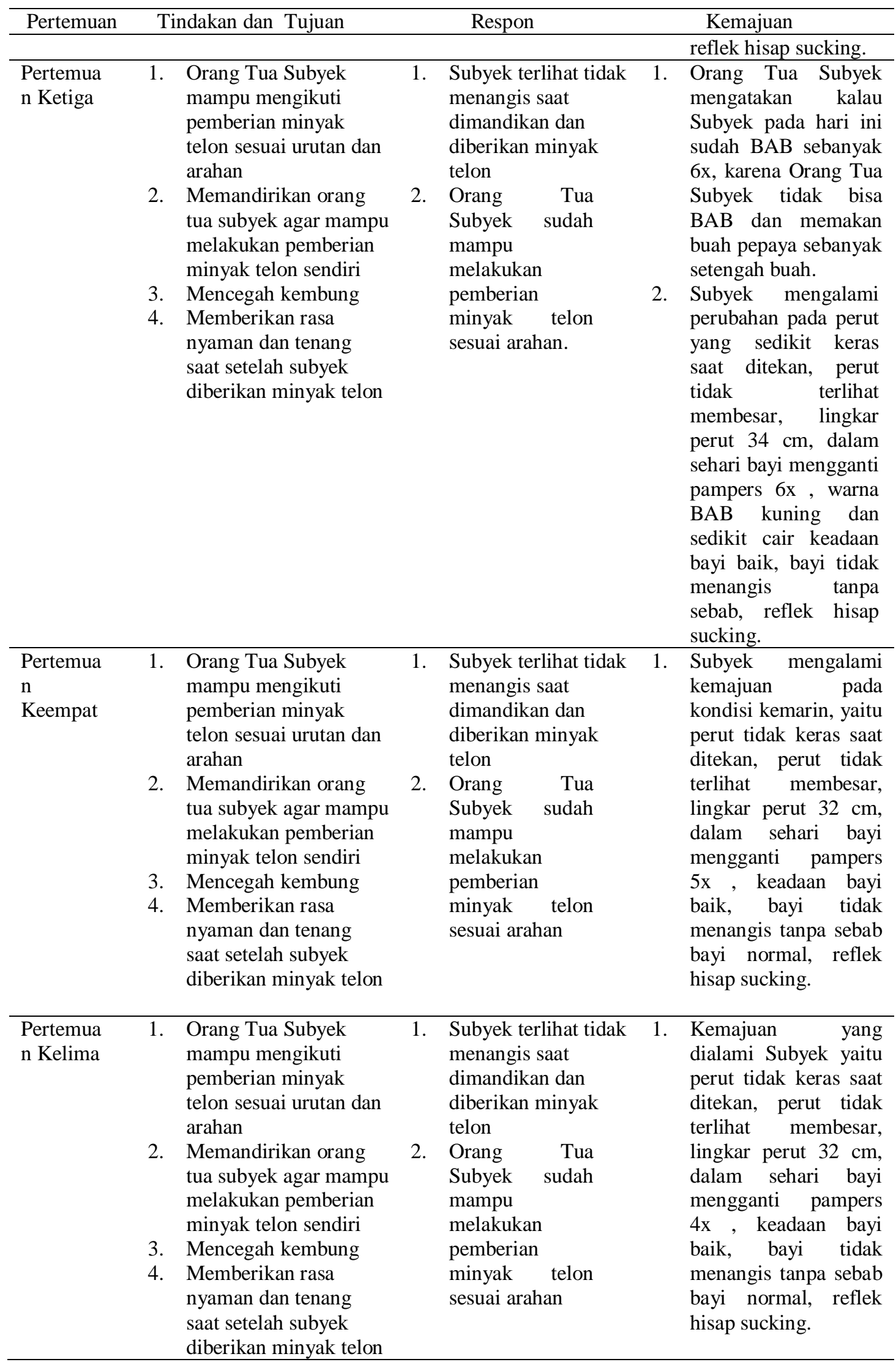


Kondisi subjek penelitian I setelah diberikan intervensi dari hasil evaluasi adalah padai hari Ke 1,2,4 dan 5 perut tidak keras saat ditekan, perut tidak terlihat membesar, lingkar perut 31-32 cm, dalam sehari Subyek I mengganti pampers 4-6kali dalam sehari, keadaan Subyek I baik. Pada hari ke 1 sampai perut tidak keras saat ditekan, perut tidak terlihat membesar, lingkar perut $31 \mathrm{~cm}$,dan pada hari ke 2 lingkar perut $31 \mathrm{~cm}$, pada hari ke 3 mengalami kenaikan menjadi $34 \mathrm{~cm}$ dan perut sedikit keras pada saat ditekan dan pada hari ke 4 dan 5 tindakan intervensi mengolesi minyak telon pada bayi dan setelah itu mengukur lingkar perut berada di kisaran $32 \mathrm{~cm}$. keadaan bayi baik dan normal tidak menangis tanpa sebab, reflek hisap sucking baik.

Tabel. 2

Proses Intervensi Subjek Penelitian II

\begin{tabular}{|c|c|c|c|}
\hline Pertemuan & Tujuan & Respon & Kemajuan \\
\hline $\begin{array}{l}\text { Pertemuan } \\
\text { Pertama }\end{array}$ & $\begin{array}{ll}\text { 1. } & \text { Tercipta hubungan } \\
\text { saling percaya } \\
\text { 2. Mendapat persetujuan } \\
\text { penelitian dari subyek } \\
\text { 3. Mengetahui tingkat } \\
\text { pengetahuan orang tua } \\
\text { Subyek I tentang } \\
\text { pemberian minyak } \\
\text { telon } \\
\text { 4. Mampu mengikuti } \\
\text { pemberian minyak } \\
\text { telon setelah mandi } \\
\text { 5. Mencegah kembung }\end{array}$ & $\begin{array}{l}\text { 1. Orang Tua Subyek I } \\
\text { sempat bingung dan } \\
\text { ragu saat dimintai } \\
\text { persetujuan untuk } \\
\text { penelitian tetap } \\
\text { kooperatif dan } \\
\text { ramah. } \\
\text { 2. Orang Tua Subyek } \\
\text { akhirnya setuju untuk } \\
\text { diberikan minyak telon } \\
\text { oleh peneliti setelah } \\
\text { Subyek I mandi setelah } \\
\text { diberikan penjelasan. } \\
\text { 3. Orang Tua Subyek I } \\
\text { belum mengetahui } \\
\text { kalau minyak telon } \\
\text { dapat mencegah } \\
\text { kembung. } \\
\text { 4. Orang Tua Subyek I } \\
\text { tidak pernah } \\
\text { memberikan minyak } \\
\text { telon kepada anaknya } \\
\text { saat masih bayi } \\
\text { sebelum puput. }\end{array}$ & $\begin{array}{l}\text { 1. Peneliti mendapat } \\
\text { kemudahan palam } \\
\text { melakukan pendekatan } \\
\text { terhadap orang tua Subyek } \\
\text { 2. Peneliti mendapatkan } \\
\text { persetujuan subyek melalui } \\
\text { surat persetujuan yang di } \\
\text { tanda tangani } \\
\text { 3. Peneliti dapat melakukan } \\
\text { intervensi kepada subyek } \\
\text { tanpa adanya paksaan. } \\
\text { 4. Subyek terjadi peningkatan } \\
\text { terhadap, Perut tidak keras } \\
\text { saat ditekan, perut tidak } \\
\text { terlihat membesar, lingkar } \\
\text { perut } 32 \text { cm, dalam sehari } \\
\text { bayi mengganti pampers } 5 x \\
\text { keadaan bayi baik, bayi } \\
\text { tidak menangis tanpa sebab, } \\
\text { bayi normal, reflek hisap } \\
\text { sucking. }\end{array}$ \\
\hline $\begin{array}{l}\text { Pertemu } \\
\text { an } \\
\text { Kedua }\end{array}$ & $\begin{array}{l}\text { 1. } \begin{array}{l}\text { Orang Tua Subyek } \\
\text { mampu mengikuti } \\
\text { pemberian minyak } \\
\text { telon sesuai urutan dan } \\
\text { arahan }\end{array} \\
\text { 2. } \begin{array}{l}\text { Memandirikan orang } \\
\text { tua subyek agar } \\
\text { mampu melakukan } \\
\text { pemberian minyak } \\
\text { telon sendiri }\end{array} \\
\text { 3. } \text { Mencegah kembung } \\
\text { 4. } \\
\text { Memberikan rasa } \\
\text { nyaman dan tenang } \\
\text { saat setelah subyek } \\
\text { diberikan minyak } \\
\text { telon }\end{array}$ & 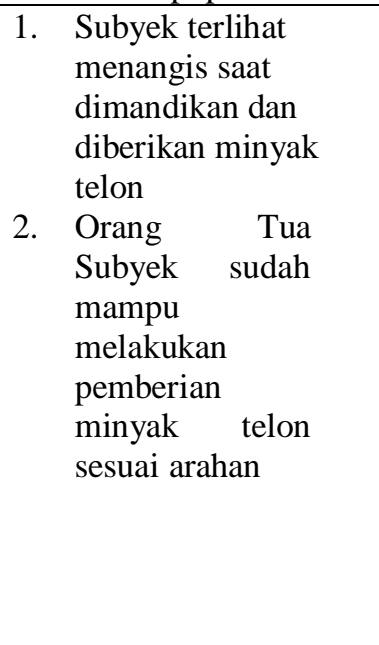 & 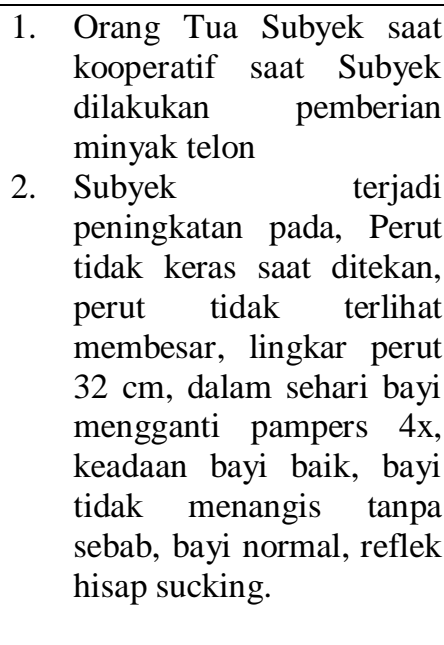 \\
\hline
\end{tabular}




\begin{tabular}{|c|c|c|c|}
\hline Pertemuan & Tujuan & Respon & Kemajuan \\
\hline $\begin{array}{l}\text { Pertemu } \\
\text { an } \\
\text { Ketiga }\end{array}$ & $\begin{array}{l}\text { 1. } \begin{array}{l}\text { Orang Tua Subyek } \\
\text { mampu mengikuti } \\
\text { pemberian minyak } \\
\text { telon sesuai urutan dan } \\
\text { arahan }\end{array} \\
\text { 2. } \begin{array}{l}\text { Memandirikan orang } \\
\text { tua subyek agar }\end{array} \\
\text { mampu melakukan } \\
\text { pemberian minyak } \\
\text { telon sendiri } \\
\text { 3. Mencegah kembung } \\
\text { 4. } \\
\text { Memberikan rasa } \\
\text { nyaman dan tenang } \\
\text { saat setelah subyek } \\
\text { diberikan minyak } \\
\text { telon }\end{array}$ & 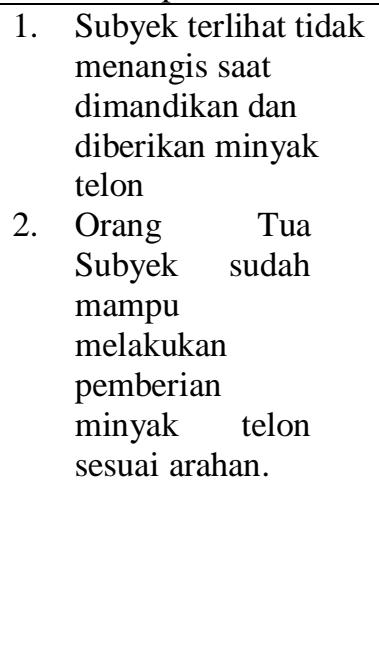 & 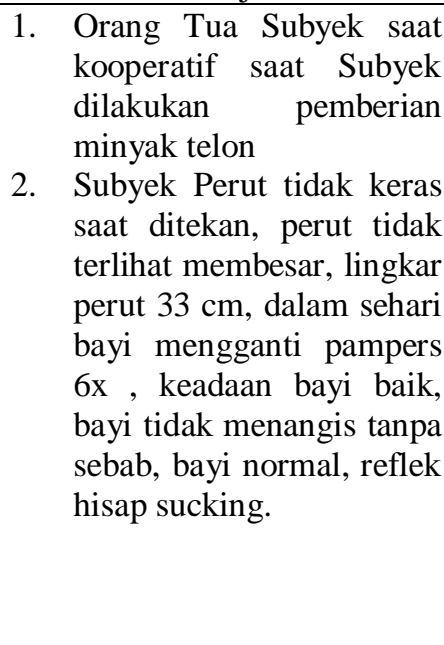 \\
\hline $\begin{array}{l}\text { Pertemua } \\
\text { n } \\
\text { Keempat }\end{array}$ & 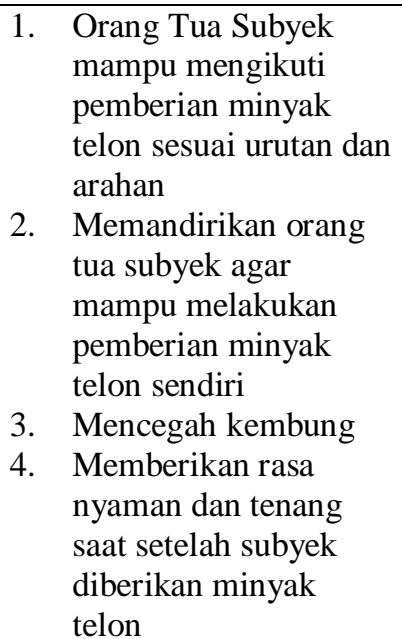 & $\begin{array}{l}\text { 1. Subyek terlihat tidak } \\
\text { menangis saat } \\
\text { dimandikan dan } \\
\text { diberikan minyak } \\
\text { telon } \\
\text { 2. Orang Tua } \\
\text { Subyek sudah } \\
\text { mampu } \\
\text { melakukan } \\
\text { pemberian telon } \\
\text { minyak tok arahan } \\
\text { sesuai arah }\end{array}$ & $\begin{array}{l}\text { Subyek mengalami kemajuan } \\
\text { yaitu, perut tidak keras saat } \\
\text { ditekan, perut tidak terlihat } \\
\text { membesar, lingkar perut } 32 \\
\mathrm{~cm} \text {, dalam sehari bayi } \\
\text { mengganti pampers } 5 \mathrm{x}, \\
\text { keadaan bayi baik, bayi tidak } \\
\text { menangis tanpa sebab, bayi } \\
\text { normal, reflek hisap sucking. }\end{array}$ \\
\hline $\begin{array}{l}\text { Pertemua } \\
\text { n Kelima }\end{array}$ & 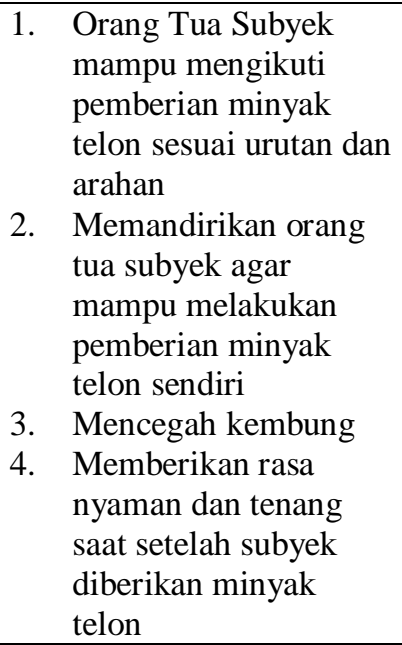 & 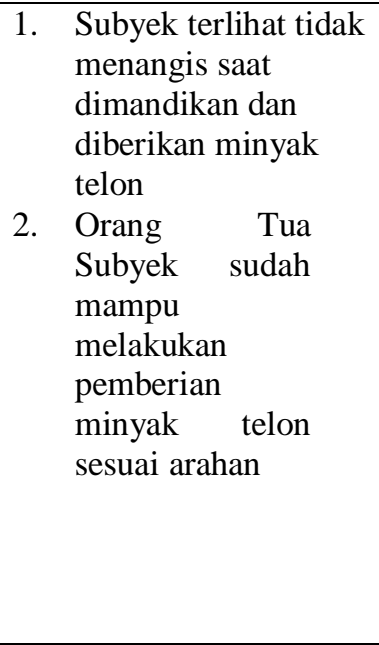 & $\begin{array}{l}\text { Kemajuan yang dialami } \\
\text { Subyek yaitu Perut tidak keras } \\
\text { saat ditekan, perut tidak } \\
\text { terlihat membesar, lingkar } \\
\text { perut } 32 \mathrm{~cm} \text {, dalam sehari bayi } \\
\text { mengganti pampers } 4 \mathrm{x}, \\
\text { keadaan bayi baik, bayi tidak } \\
\text { menangis tanpa sebab, bayi } \\
\text { normal, reflek hisap sucking. }\end{array}$ \\
\hline
\end{tabular}

Kondisi subjek penelitian II setelah diberikan intervensi dari hasil evaluasi adalah mengalami kemajuan pada hari Ke 1 sampai Ke 5 perut tidak keras saat ditekan dan tidak mengalami pembesaran, perut tidak terlihat membesar, lingkar perut $32-33 \mathrm{~cm}$, dalam sehari Subyek II mengganti pampers 4-6 kali dalam sehari, keadaan Subyek 
mengalami perbaikan dalam perawatan. Subyek II bayi normal tidak menangis tanpa sebab, dan reflek hisap sucking baik.

Tabel. 3

Perbandingan Kondisi Klien Sebelum dan Sesudah Dilakukan Intervensi pada Subjek I dan II

\begin{tabular}{|c|c|c|c|}
\hline Hari & Aspek & Sebelum & Sesudah \\
\hline \multirow[b]{2}{*}{ I } & $\begin{array}{l}\text { Ukuran } \\
\text { Bayi }\end{array}$ & $\begin{array}{lll}\text { Ukuran perut bayi } & \text { sebelum } \\
\text { diberikan minyak telon } & \text { berkisar } \\
32 \mathrm{~cm} & & \\
\end{array}$ & $\begin{array}{l}\text { Ukuran perut bayi setelah diberikan } \\
\text { minyak telon berkisar } 31 \mathrm{~cm}\end{array}$ \\
\hline & Aktifitas Bayi & $\begin{array}{l}\text { Bayi tampak tenang, tidak } \\
\text { banyak bergerak, menangis perut } \\
\text { bayi tidak keras, tidak menarik- } \\
\text { narik kaki ke arah perut }\end{array}$ & $\begin{array}{l}\text { Bayi tampak tenang, tidak banyak } \\
\text { bergerak, menangis perut bayi tidak } \\
\text { keras, tidak menarik-narik kaki ke arah } \\
\text { perut }\end{array}$ \\
\hline \multirow[b]{2}{*}{ II } & $\begin{array}{l}\text { Ukuran } \\
\text { Bayi }\end{array}$ & $\begin{array}{l}\text { Ukuran perut bayi sebelum } \\
\text { diberikan minyak telon berkisar } \\
30 \mathrm{~cm}\end{array}$ & $\begin{array}{l}\text { Ukuran perut bayi setelah diberikan } \\
\text { minyak telon berkisar } 31 \mathrm{~cm}\end{array}$ \\
\hline & Aktifitas Bayi & $\begin{array}{l}\text { Bayi tampak tenang, tidak } \\
\text { banyak bergerak, menangis perut } \\
\text { bayi tidak keras, tidak menarik- } \\
\text { narik kaki ke arah perut }\end{array}$ & $\begin{array}{l}\text { Bayi tampak tenang, tidak banyak } \\
\text { bergerak, menangis perut bayi tidak } \\
\text { keras, tidak menarik-narik kaki ke arah } \\
\text { perut }\end{array}$ \\
\hline \multirow[b]{2}{*}{ III } & $\begin{array}{l}\text { Ukuran } \\
\text { Bayi }\end{array}$ & $\begin{array}{l}\text { Ukuran perut bayi sebelum } \\
\text { diberikan minyak telon berkisar } \\
30 \mathrm{~cm}\end{array}$ & $\begin{array}{l}\text { Ukuran perut bayi setelah diberikan } \\
\text { minyak telon berkisar } 32 \mathrm{~cm}\end{array}$ \\
\hline & Aktifitas Bayi & $\begin{array}{l}\text { Bayi tampak tenang, tidak } \\
\text { banyak bergerak, menangis perut } \\
\text { bayi tidak keras, tidak menarik- } \\
\text { narik kaki ke arah perut }\end{array}$ & $\begin{array}{l}\text { Bayi tampak tenang, tidak banyak } \\
\text { bergerak, menangis perut bayi tidak } \\
\text { keras, tidak menarik-narik kaki ke arah } \\
\text { perut }\end{array}$ \\
\hline \multirow[b]{2}{*}{ IV } & $\begin{array}{l}\text { Ukuran } \\
\text { Bayi }\end{array}$ & $\begin{array}{l}\text { Ukuran perut bayi } \text { sebelum } \\
\text { diberikan minyak telon berkisar } \\
31 \mathrm{~cm}\end{array}$ & $\begin{array}{l}\text { Ukuran perut bayi setelah diberikan } \\
\text { minyak telon berkisar } 31 \mathrm{~cm}\end{array}$ \\
\hline & Aktifitas Bayi & $\begin{array}{l}\text { Bayi tampak tenang, tidak } \\
\text { banyak bergerak, menangis perut } \\
\text { bayi tidak keras, tidak menarik- } \\
\text { narik kaki ke arah perut }\end{array}$ & $\begin{array}{l}\text { Bayi tampak tenang, tidak banyak } \\
\text { bergerak, menangis perut bayi tidak } \\
\text { keras, tidak menarik-narik kaki ke arah } \\
\text { perut }\end{array}$ \\
\hline \multirow[b]{2}{*}{$\mathrm{V}$} & $\begin{array}{l}\text { Ukuran } \\
\text { Bayi }\end{array}$ & $\begin{array}{l}\text { Ukuran perut bayi sebelum } \\
\text { diberikan minyak telon berkisar } \\
31 \mathrm{~cm}\end{array}$ & $\begin{array}{l}\text { Ukuran perut bayi setelah diberikan } \\
\text { minyak telon berkisar } 32 \mathrm{~cm}\end{array}$ \\
\hline & Aktifitas Bayi & $\begin{array}{l}\text { Bayi tampak tenang, tidak } \\
\text { banyak bergerak, menangis perut } \\
\text { bayi tidak keras, tidak menarik- } \\
\text { narik kaki ke arah perut }\end{array}$ & $\begin{array}{l}\text { Bayi tampak tenang, tidak banyak } \\
\text { bergerak, menangis perut bayi tidak } \\
\text { keras, tidak menarik-narik kaki ke arah } \\
\text { perut }\end{array}$ \\
\hline
\end{tabular}

Kondisi subjek penelitian I setelah diberikan intervensi dari hasil evaluasi adalah pada hari pertama dan kedua perut tidak keras saat ditekan, perut tidak terlihat membesar, lingkar perut 31-32 cm, dalam sehari subyek I mengganti pampers $4 \mathrm{x}$, keadaan subyek I baik. Pada hari ke 3 Perut sedikit keras saat ditekan, perut tidak terlihat membesar, lingkar perut $34 \mathrm{~cm}$, dalam sehari bayi mengganti pampers $6 x$, warna BAB kuning dan sedikit cair keadaan bayi baik, bayi tidak menangis tanpa sebab bayi normal. Hari ke 4 dan 5 perut tidak keras saat ditekan, perut tidak terlihat membesar, lingkar perut $32 \mathrm{~cm}$, dalam sehari bayi mengganti pampers $4 \mathrm{x}$, subyek I tidak menangis 
tanpa sebab, reflek hisap sucking. Kondisi subjek penelitian II setelah diberikan intervensi dari hasil evaluasi pada hari pertama sampai kelima perut tidak keras saat ditekan, perut tidak terlihat membesar, lingkar perut rata-rata dalam hari pertama sampai kelima berkisar 32-33 cm, dalam sehari bayi mengganti pampers 5x, Subyek Penelitain II tidak menangis tanpa sebab.

\section{PEMBAHASAN}

Subjek penelitian I dan II tidak terjadi kembung. Subjek penelitian I bernama Bayi Ny. A berumur 1 hari, jenis kelamin perempuan dan subjek penelitian II bernama Bayi Ny. T berumur 1 hari, berjenis kelamin laki-laki. Pencegahan perut kembung pada bayi baru lahir yang dilakukan selama 5 hari berturut-turut dimana kedua subjek penelitian sama-sama diberikan intervensi pemberian minyak telon. Hal ini didukung oleh penelitian yang dilakukan (Riani, 2018).

Subjek penelitian I dan II yang diberikan minyak telon setelah mandi memiliki usia 1 hari, peneliti mengambil kriteria bayi baru lahir dengan usia $<7$ hari karena bayi baru lahir rentan terkena masalah-masalah pada pencernaan. Hal ini didukung oleh penelitian yang dilakukan oleh Riani (2018) masalah perut kembung bayi baru lahir biasanya disebabkan oleh menelan udara karena kesalahan posisi saat Ibu menyusui atau diberi minum lewat botol, bayi menangis berlebihan, adanya gangguan pencernaan, adanya virus yang menyebabkan muntah dan diare, bayi baru mendapatkan makanan padat sehingga gas meningkat dan bayi banyak mengoceh serta saluran pencernaan yang belum berfungsi sepenuhnya. Terdapat gas atau udara yang berlebih dalam saluran pencernaan yang akhirnya membuat perut bayi kembung. Pada anak yang lebih dewasa, gas tersebut lebih mudah untuk dikeluarkan. Sedangkan pada bayi baru lahir, mekanisme tubuhnya belum mampu mengeluarkan gas sendiri. Sehingga membutuhkan bantuan orangtua untuk mengeluarkannya.

Ada perbedaan pola asuh pada subjek penelitian I dan II. Subjek penelitian I sudah memiliki 2 anak, dan kedua anaknya diasuh sendiri oleh $\mathrm{Ny}$. A sehingga setiap setelah mandi Ny. A selalu memberikan minyak telon kepada bayinya untuk menghangatkan tubuh sang bayi dengan cara mengoleskan minyak telon pada perut bayi searah dengan jarum jam dan menambahkannya di punggung bayi. Sedangkan subjek penelitian II sudah memiliki 1 anak tinggal bersama dengan orang tua $\mathrm{Ny}$. $\mathrm{T}$ dan anak pertama Ny. T baru berusia 2 tahun, By. Ny T. lebih banyak diasuh oleh orang tua $\mathrm{Ny}$. T. karena Ny. T. sibuk bekerja disamping itu Ny. T. belum banyak pengalaman dalam mengasuh bayinya sehingga bayi Ny. T. lebih banyak diserahkan bayinya untuk diurus oleh Ibu nya sedangkan Ny. T. memiliki kepercayaan tidak memberikan minyak telon kepada bayi sebelum tali pusat puput, dengan alasan jika diberi minyak telon takut masuk ke dalam tali pusat sehingga menimbulkan infeksi.

Dari hasil penelitian yang dilakukan oleh peneliti kepada kedua subjek penelitian yaitu pada By. Ny. A pada hari pertama sebelum diberikan pemberian minyak telon lingkar perut $29 \mathrm{~cm}$, dengan keadaan perut bayi lembek, bayi tidak banyak bergerak, dan bayi tidak sering menangis tanpa sebab, kemudian setelah dilakukan penelitian Subyek Penelitian I bayi tidak terjadi kembung, tetapi pada saat hari ketiga perut bayi agak sedikit keras, hal tersebut mungkin dipengaruhi oleh faktor ASI ibu Subyek Penelitian I, karena Ibu Subyek Penelitian I sebelumnya memakan setengah buah papaya tetapi keesokkan harinya perut subyek penelitian I tampak normal kembali. 
Subyek I saat dirumah tidak pernah menangis tanpa sebab, subyek I hanya menangis kalau haus, saat BAB dan BAK saja dan tidak pernah gumoh.

Pada subyek penelitian II sebelum dilakukan pemberian minyak telon lingkar perut $30 \mathrm{~cm}$, dengan keadaan perut bayi lembek, bayi tidak banyak bergerak, bayi tidak sering menangis tanpa sebab dan setelah dilakukan penelitian bayi tidak terjadi kembung, bayi tidak enangis tanpa sebab, bayi tidak banyak bergerak, bayi menangis apabila haus, kepanasan, saat buang air besar dan buang air kecil saja, selain itu bayi tidak pernah gumoh. Hasil penelitian tersebut didukung oleh beberapa teori dan hasil penelitian, salah satunya yaitu hasil penelitian yang dilakukan oleh Wicaksono (2017) bahwa bayi yang baru lahir bila diberikan minyak telon secara rutin pagi dan sore setiap kali habis dimandikan tetapi apabila bayi tetap mengalami perut kembung setelah diberi minyak telon dan bayi menjadi rewel sebaiknya segera diperikasana ke dokter. Masuk angin atau perut kembung merupakan Asterik terdapatnya gas yang berlebih dalam perut. Untuk mengatasinya ambilah beberapa lembar daun jarak pagar yang tua, bersihkan dari debu kemudian layukan di atas api, jangan sampai hangus daunnya. Setelah daun layu oleskan minyak kelapa, minyak telon atau minyak kayu putih. setelah itu tempelkan di bagian perut dan pinggang. Biarkanlah beberapa jam. Biasanya akan terjadi deportasi gas yang membuat perut lebih lega (Riani, 2018).

\section{SIMPULAN}

Saat melakukan pengkajian bayi memiliki masa gestasi sesuai dengan kriteria inklusi dan melakukan intervensi pemberian minyak telon dengan mengunakan minyak telon pada perut bayi dengan gerakan seperti menulis ILU (I Love You) agar mendorong gas yang berlebih keluar dari pembuangan gas, atau mengoleskan minyak telon pada perut bayi searah jarum jam yang dilakukan pagi dan sore selain bertujuan untuk mencegah kembung juga bertujuan untuk menghangatkan tubuh karena kandungan yang terdapat dalam minyak telon memiliki 3 kandungan minyak, yaitu terdiri dari minyak kelapa, kayu putih, dan minyak adas.

\section{SARAN}

\section{Bagi Institusi Pendidikan}

Hendaknya institusi memberikan fasilitas buku-buku referensi yang terkait dengan pelajaran maternitas khususnya materi tentang cara pencegahan perut gembung pada bayi, yang lebih banyak agar memudahkan peneliti dalam mencari referensi sehingga peneliti mudah untuk menyelesaikan penelitiannya.

\section{Bagi Peneliti}

Diharapkan untuk lahan praktik bisa diperluas lagi, sehingga mahasiswa bisa dengan mudah untuk mendapatkan klien untuk penelitiannya dan memberikan pendidikan kesehatan kepada klien sebelum klien pulang sebagai bekal klien untuk perawatan dirumah.

\section{Bagi masyarakat}

Diharapkan bisa menggunakan metode pemberian minyak telon dengan menggunakan minyak telon ini agar dapat mencegah perut kembung pada bayi dan menghangatkan perut bayi. 


\section{DAFTAR PUSTAKA}

IDAI. (2017). Kembung. Jakarta: Indonesian Pediatric Society

Martha, H. D. (2016). Ini Sebabnya Bayi Rentan Mengalami Perut Kembung. Jakarta: Detik Health. Diambil pada tanggal 3 Mei 2019 pukul 20.10 WIB Dari https://health.detik.com/bayi/d-3175992/ini-sebabnya-bayi-rentan-mengalamiperut-kembung

Padila, P., \& Agustien, I. (2019). Suhu Tubuh Bayi Prematur di Inkubator Dinding Tunggal dengan Inkubator Dinding Tunggal Disertai Sungkup. Jurnal Keperawatan Silampari, 2(2), 113-122. https://doi.org/10.31539/jks.v2i2.651

Padila, P., Amin, M., \& Rizki, R. (2018). Pengalaman Ibu dalam Merawat Bayi Preterm yang Pernah dirawat di Ruang Neonatus Intensive Care Unit Kota Bengkulu. Jurnal Keperawatan Silampari, 1(2), 1-16. https://doi.org/10.31539/jks.v1i2.82

Padila, P., Andari, F. N., \& Andri, J. (2019). Hasil Skrining Perkembangan Anak Usia Toddler antara DDST dengan SDIDTK. Jurnal Keperawatan Silampari, 3(1), 244-256. https://doi.org/10.31539/jks.v3i1.809

Padila, P., Febriawati, H., Andri, J., \& Dori, R. A. (2019). Perawatan Infeksi Saluran Pernafasan Akut (Ispa) pada Balita di Wilayah Kerja Puskesmas. Jurnal Kesmas Asclepius, 1(1), 25-34. https://doi.org/10.31539/jka.v1i1.526

Padila, P. (2015). Asuhan Keperawatan Maternity I. Yogyakarta: Nuha Medika

Riani, R. (2018). Perbandingan Efektivitas Daun Jarak dan Minyak Kayu Putih dengan Daun Jarak Tanpa Minyak Kayu Putih terhadap Kesembuhan Perut Kembung Pada Bayi 0 - 2 Tahun di Wilayah Kerja Puskesmas Bangkinang Kota Tahun 2017/2018. Jurnal Ners, 2(2), 71-81

Solarbesain, F. H. P., \& Pudjihastuti, I. (2019). Pengaruh Komposisi pada Minyak Telon terhadap Uji Indeks Bias dengan Menggunakan Refraktometer Tipe Way Abbe. Metana, 15(1), 32-36. https://doi.org/ 10.14710/metana.v15i1.20330

Wicaksono, A. (2017). Manfaat Menggunakan Minyak Telon bagi Bayi dan Dewasa. Jakarta: CNN Indonesia. Diambil pada tanggal 3 Mei 2019 pukul 20.20 WIB https://www.cnnindonesia.com/gaya-hidup/20190220150321-25537105/ manfaatmenggunakan-minyak-telon-bagi-bayi-dan-dewasa 